\title{
May C-peptide index be a new marker to predict proteinuria in anemic patients with type 2 diabetes mellitus?
}

\author{
Bilal Katipoglu${ }^{1}$, Mustafa Comoglu ${ }^{1}$, Ihsan Ates ${ }^{1}$, Nisbet Yilmaz ${ }^{1}$, Dilek Berker ${ }^{2}$ \\ ${ }^{1}$ Department of Internal Medicine, Ankara Numune Training and Research Hospital, Ankara, Turkey; \\ ${ }^{2}$ Department of Endocrinology, Ankara Numune Training and Research Hospital, Ankara, Turkey \\ E-mail:drbilal07@gmail.com
}

Objective. C-peptide is a reliable marker of beta cell reserve and is associated with diabetic complications. Furthermore, $\mathrm{HbAlc} \mathrm{level} \mathrm{is} \mathrm{associated} \mathrm{with} \mathrm{micro-} \mathrm{and} \mathrm{macro-vascular} \mathrm{complica-}$ tions in diabetic patients. HbAlc measurement of diabetic patients with anemia may be misleading because $\mathrm{HbAlc}$ is calculated in percent by taking reference to hemoglobin measurements. We hypothesized that there may be a relationship between C-peptide index (CPI) and proteinuria in anemic patients with type 2 diabetes mellitus (T2DM). Therefore, the aim of the present study was to investigate the association between C-peptide levels and CPI in anemic patients with T2DM and proteinuria.

Methods. The patients over 18 years of age with T2DM whose C-peptide levels were analyzed in Endocrinology and Internal medicine clinics between 2014 and 2018 with normal kidney functions (GFR $>60 \mathrm{ml} / \mathrm{min}$ ) and who do not use any insulin secretagogue oral antidiabetic agent (i.e. sulfonylurea) were enrolled into the study.

Results. Hemoglobin levels were present in 342 patients with T2DM. Among these 342 cases, $258(75.4 \%)$ were non-anemic whereas $84(24.6 \%)$ were anemic. The median DM duration of the anemic group was statistically significantly higher in T2DM ( $\mathrm{p}=0.003)$. There was no statistically significant difference found in proteinuria prevalence between non-anemic and anemic patient groups ( $\mathrm{p}=0.690$ and $\mathrm{p}=0.748$, respectively). Anemic T2DM cases were corrected according to the age, gender, and duration of DM. C-peptide and CPI levels were not statistically significant to predict proteinuria $(\mathrm{p}=0.449$ and $\mathrm{p}=0.465$, respectively).

Conclusion. The present study sheds light to the association between C-peptide, CPI, and anemic diabetic nephropathy in T2DM patients and indicates that further prospective studies are needed to clarify this issue.

Key words: C-peptide, C-peptide index, diabetic nephropathy

The C-peptide level is used to demonstrate the pancreas beta cell reserve in clinical practice. C-peptide is currently accepted as an active hormonal molecule (Sari and Balci 2005). It plays an important role in the blood glucose regulation by activating many pathways at the cell level. In addition, several studies have shown that C-peptide level may be associ- ated with microvascular complications in the patients with type 1 (T1) and type 2 diabetes mellitus (T2DM) (Luppi et al. 2013). A negative correlation has been found between microvascular complications such as diabetic nephropathy and C-peptide levels in the patients with T1DM (Panero et al. 2009). On the other hand, T2DM patients with increased C-peptide levels

Corresponding author: Bilal Katipoglu, M.D., Ankara Numune Training and Research Hospital, Department of Internal Medicine, Sihhiye, 06100, Ankara, Turkey; e-mail: drbilal07@gmail.com. 
were associated with macrovascular complications whereas decreased C-peptide levels were associated with microvascular complications (Inukai et al. 1999).

Blood glucose regulation is very important in diabetic patients and HbAlc is one of the most important parameters for development diabetic complications (Rohlfing et al. 2002). HbAlc level is associated with micro- and macro-vascular complications in diabetic patients (The DCCT Research Group 1995; Heisler et al. 2005). HbA1c measurement in anemic diabetic patients may be misleading, because HbAlc is calculated in percentages depending on the hemoglobin measurements (Schnedl et al. 2000). Although this margin of error is reduced by new biochemical methods, it is not possible to measure with same method in each center.

In the light of the previous studies, we thought that C-peptide level could predict blood glucose regulation in anemic patients rather than $\mathrm{HbAlc}$, which is one of the most important parameters to predict microvascular complications. On the other hand, C-peptide level may be affected by fasting blood glucose and for that reason, we formed C-peptide index (CPI) by proportioning the C-peptide level to blood glucose. Therefore, we aimed to investigate the relation between $\mathrm{C}$-peptide and CPI levels in the anemic patients with T2DM presenting proteinuria.

\section{Materials and methods}

Subjects. This retrospective study was performed in Ankara Numune Training and Research Hospital Internal Diseases Clinic between June 2018 and September 2018.

A total of 342 patients with T2DM, whose C-peptide levels were analyzed in Endocrinology and Internal medicine clinics between 2014 and 2018 with normal kidney functions (GFR $>60 \mathrm{ml} / \mathrm{min}$ ) and who do not use any insulin secretagogue oral antidiabetic agent (i.e. sulfonylurea) were enrolled into the study.

The study was approved in accordance with the patient rights regulation and approved by Scientific Research Evaluation Commission of Ankara Numune Training and Research Hospital on the date of 25/05/2018 with the decision number 1990-2018.

Parameters. Laboratory parameters were recorded from electronic files of the patients.

Hemoglobin $<12 \mathrm{mg} / \mathrm{dl}$ was considered anemia in female patients, hemoglobin $<13 \mathrm{mg} / \mathrm{dl}$ was considered anemia in male patients.

C-peptide index (CPI) (ng/mg) was calculated by the formula: fasting C-peptide immunoreactivity
$($ FCPR $)(\mathrm{ng} / \mathrm{ml}) /$ fasting blood glucose $(\mathrm{mg} / \mathrm{dl}) \times 100$.

Ratio of albumin-creatinine in the spot urine ranged from 30 to $300 \mathrm{mg}$ was considered to be microalbuminuria, ratio of albumin-creatinine in the spot urine over $300 \mathrm{mg}$ was considered to be overt proteinuria.

Statistical analysis. Kolmogrov-Smirnov test and Levene's test were utilized to determine the distribution of data and homogeneity of variance. Normally distributed numerical variables were expressed as mean \pm standard deviation, while non-normally distributed variables were given as median (25th75th percentile).

The significance of the difference for continuous numerical variables was analyzed by Kruskal Wallis test. If Kruskal Wallis test statistics were found to be significant, Conover test of multiple comparisons was used to determine the difference in the group(s).

When correction was done according to the age, gender, and duration of diabetes mellitus, the most determinant factor(s) for prediction of the changes in (C-peptide, CPI) measurements was detected through multiple variable regression analyses. As a result of univariate statistical analysis, the variables determined as $\mathrm{p}<0.10$ were included as candidate risk factors in regression analysis. Regression coefficient, 95\% confidence intervals and $t$ statistics for each variable were calculated. Since C-peptide measurements were not normally distributed, logarithmic transformation was performed in multivariate linear regression analysis.

Data were analyzed using IBM SPSS Statistics 17.0 (IBM Corporation, Armonk, NY, USA). Results for $\mathrm{p}<0.05$ were considered statistically significant.

\section{Results}

Hemoglobin levels were present in 342 patients with T2DM. Among 342 cases, 258 (75.4\%) were nonanemic, while $84(24.6 \%)$ were anemic.

The median DM duration of the anemic group was statistically significantly higher in T2DM $(p=0.003)$. There was no statistically significant difference found in proteinuria prevalence between non-anemic and anemic groups $(p=0.690$ and $\mathrm{p}=0.748$, respectively). Low-density lipoprotein (LDL) cholesterol and high-density lipoprotein (HDL) cholesterol were statistically similar between the non-anemic group and anemic group $(\mathrm{p}=0.053$ and $\mathrm{p}=0.096$, respectively). C-peptide and CPI levels were statistically similar between the non-anemic group and anemic group $(\mathrm{p}=0.062$ and $\mathrm{p}=0.170$, respectively) (Table 1 ). 
C-peptide and CPI levels were not statistically significant in anemic patients with T2DM ( $>0.05)$ (Table 2).

Anemic patients with T2DM were corrected according to the age, gender and duration of DM. C-peptide and CPI levels detected were not statistically significant to predict proteinuria ( $\mathrm{p}=0.449$ and $\mathrm{p}=0.465$, respectively) (Table 3 ).

\section{Discussion}

Three important outcomes can be depicted from the present study. First, the duration of diabetes was longer in T2DM patients with anemic than in nonanemic DM patients. Second, there was not statistically significant difference found in C-peptide and

Table 1

Clinical features of cases with type 2 diabetes mellitus anemic and non-anemic groups.

\begin{tabular}{lccc}
\hline & Non-anemic & Anemic & p value \\
\hline DM duration & $4(2-10)$ & $8(4-15)$ & $0.003 \dagger$ \\
Proteinuria & & & $0.748 \ddagger$ \\
Negative & $134(62.9 \%)$ & $45(60.8 \%)$ & \\
Positive & $79(37.1 \%)$ & $29(39.2 \%)$ & \\
LDL (mg/dl) & & & $0.053 \ddagger$ \\
$\leq 100$ & $97(38.3 \%)$ & $40(50.6 \%)$ & \\
$>100$ & $156(61.7 \%)$ & $39(49.4 \%)$ & \\
HDL (mg/dl) & & & $0.096 \ddagger$ \\
$\leq 40$ & $180(\% 71,1)$ & $49(61.3 \%)$ & \\
$>40$ & $73(\% 28,9)$ & $31(38.8 \%)$ & \\
C-peptide (ng/ml) & $2.2(1.5-3.3)$ & $2.0(1.2-2.8)$ & $0.062 \dagger$ \\
CPI & $1.4(0.7-2.2)$ & $1.2(0.8-1.9)$ & $0.170 \dagger$ \\
\hline
\end{tabular}

Descriptive statistics: median $\left(25^{\text {th }}-75^{\text {th }}\right)$ percentile for continuous numerical variables, and number of cases and (\%) for categorical variables; $\uparrow$ Mann Whitney U test; $\ddagger$ Pearson’s Chi-square test. Abbreviations: LDL - low-density lipoprotein cholesterol; HDL - high-density lipoprotein cholesterol; CPI C-peptide index.

Table 2

C-peptide and CPI levels of anemic type 2 diabetes mellitus patients.

\begin{tabular}{lcc}
\hline & C-peptide $(\mathbf{n g} / \mathrm{ml})$ & CPI \\
\hline Proteinuria & & \\
Negative & $2.2(1.2-2.8)$ & $1.3(0.8-1.9)$ \\
Positive & $1.6(1.1-2.7)$ & $1.0(0.6-1.6)$ \\
p-value $\dagger$ & 0.678 & 0.301 \\
\hline
\end{tabular}

Descriptive statistics: median $\left(25^{\text {th }}-75^{\text {th }}\right)$ expressed in percentile; $\dagger$ Mann Whitney U test. Abbreviations: CPI - C-peptide index.
CPI levels between anemic and non-anemic groups. Previous studies have shown that a negative correlation with anemia and C-peptide levels and this may be the result of a large sample size. Third, we found that C-peptide and CPI were not significant to predict proteinuria in anemic diabetic patients.

In fact, it has long been known that anemia is very common in T2DM patients (Thomas et al. 2003). Diabetic patients with or without diabetic nephropathy were shown to have a decrease in hemoglobin concentrations over time (Zoppini et al. 2010). In addition, it is thought that beta cell loss may be secondary to anemia-induced tissue hypoxia (Thomas 2007). It has been demonstrated that hypoxia-induced oxidative stress may be associated with diabetic progression in experimental models, particularly in the loss of beta cell reserve (Sato et al. 2011; Gerber and Rutter 2017). Sato et al. (2014) have also found that insulin secretion decreased with hypoxia. In another study supporting this issue has reported that patients with obstructive sleep apnea have an increased risk of diabetes secondary to chronic hypoxemia (Botros et al. 2009). Furthermore, beta cell loss due to hypoxia has been found to be associated with apoptosis (Butler et al. 2003). The cross-sectional studies have shown that T2DM patients have a relationship between beta cell reserve and anemia (He et al. 2015; Chung et al. 2017). In addition, increased oxidative stress and free oxygen radicals due to anemia have been shown to cause pancreatic beta cells to be more susceptible to oxidative stress (Kundu et al. 2013). Furthermore,

Table 3

Analysis of the effects of laboratory measurements on proteinuria by multivariate logistic regression analysis when corrected according to age, gender and duration of diabetes mellitus (DM) in anemic type 2 diabetes mellitus patients

\begin{tabular}{|c|c|c|c|c|c|}
\hline & \multirow{2}{*}{$\begin{array}{l}\text { Odds } \\
\text { ratio }\end{array}$} & \multicolumn{2}{|c|}{$\begin{array}{c}\text { 95\% Confidence } \\
\text { interval }\end{array}$} & \multirow{2}{*}{ Wald } & \multirow{2}{*}{ p-value } \\
\hline & & $\begin{array}{c}\text { Lower } \\
\text { limit }\end{array}$ & $\begin{array}{l}\text { Upper } \\
\text { limit }\end{array}$ & & \\
\hline \multicolumn{6}{|l|}{ Model 1} \\
\hline Age & 0.973 & 0.924 & 1.024 & 1.113 & 0.291 \\
\hline Male factor & 2.685 & 0.729 & 9.890 & 2.204 & 0.138 \\
\hline DM duration & 0.971 & 0.880 & 1.072 & 0.333 & 0.564 \\
\hline C-peptide & 1.166 & 0.784 & 1.734 & 0.574 & 0.449 \\
\hline \multicolumn{6}{|l|}{ Model 2} \\
\hline Age & 0.978 & 0.929 & 1.030 & 0.699 & 0.403 \\
\hline Male factor & 2.947 & 0.786 & 11.047 & 2.570 & 0.109 \\
\hline DM duration & 0.935 & 0.841 & 1.040 & 1.535 & 0.215 \\
\hline C-peptide index & 0.793 & 0.425 & 1.478 & 0.534 & 0.465 \\
\hline
\end{tabular}


there has been a negative correlation between anemia and C-peptide levels described (Chung et al. 2018).

Previous studies have shown an association between anemia and organ damage due to diabetes mellitus and an increase in the incidence of microvascular complications (Thomas 2007; Hosseini et al. 2014). Furthermore, anemia is associated with an increased risk of diabetic retinopathy (Ranil et al. 2010). It has been shown that diabetic nephropathy progresses rapidly with anemia (Mohanram et al. 2004).

In other studies, the relationship between diabetic nephropathy and C-peptide, which is considered as active hormonal molecule, has been investigated. Recently, it has been shown that there was an inverse association between CPI and the diabetic nephropathy (Samnegard et al. 2001; Hills et al. 2010). We could not find any study in the literature regarding the prediction of proteinuria in anemic T2DM patients with C-peptide level and CPI. To the best of our knowledge, this is the first study to evaluate the relationship between C-peptide and CPI levels with proteinuria in the anemic patients with T2DM.

CPI is more accurate predictive beta cell function than C-peptide measurements (Kim et al. 2016). Furthermore, if significant hyperglycemia persists, C-peptide levels may also be found to be lower than normal due to glucose toxicity (Jones and Hattersley
2013). Besides, since glucose itself is a great stimulant for pancreas cells, insulin secretion is increased by the amount of high glucose (Saisho 2016). For that reason, the $\mathrm{C}$-peptide level may also be higher than normal. Therefore, level of C-peptide should be adjusted by glucose for evaluation of beta cell function. CPI is formed by dividing the C-peptide level into fasting blood glucose (Lee et al. 2014). In many studies, CPI has been found to be more closely associated with beta cell function, insulin requirement, and microvascular complications (Saisho et al. 2013; Lee et al. 2014; Saisho 2016; Bando et al. 2018). In our study, we could not demonstrate that CPI is used to predict proteinuria in anemic patients. The size of research populations may have led to these results. Obviously, further studies with a larger number of patients and a longer observation period are needed to address this issue.

The present study has some limitations including single center design and limited number of the patients, lack of causes for anemia detected data recording from the system. Moreover, prospective randomized controlled trials are needed to determine the causal relationship between anemia and C-peptide levels.

Consequently, this study sheds light to the association between C-peptide, CPI and anemic diabetic nephropathy in T2DM patients.

\section{References}

Bando H, Ebe K, Muneta T, Bando M, Yonei Y. Investigation of fasting ratio of C-peptide/glucose and related markers in diabetes. Archives of Diabetes and Endocrine System 1, 17-24, 2018.

Botros N, Concato J, Mohsenin V, Selim B, Doctor K, Yaggi HK. Obstructive sleep apnea as a risk factor for type 2 diabetes. Am J Med 122, 1122-1127, 2009.

Butler AE, Janson J, Bonner-Weir S, Ritzel R, Rizza RA, Butler PC. Beta-cell deficit and increased beta-cell apoptosis in humans with type 2 diabetes. Diabetes 52, 102-110, 2003.

Chung JO, Park SY, Cho DH, Chung DJ, Chung MY. Anemia, bilirubin, and cardiovascular autonomic neuropathy in patients with type 2 diabetes. Medicine 96, e6586, 2017.

Chung JO, Park SY, Cho DH, Chung DJ, Chung MY. Anemia is inversely associated with serum C-peptide concentrations in individuals with type 2 diabetes. Medicine 97, e11783, 2018.

Gerber PA, Rutter GA. The role of oxidative stress and hypoxia in pancreatic beta-cell dysfunction in diabetes mellitus. Antioxid Redox Signal 26, 501-518, 2017.

He BB, Xu M, Wei L, Gu YJ, Han JF, Liu YX, Bao YQ, Jia WP. Relationship between anemia and chronic complications in Chinese patients with type 2 diabetes mellitus. Arch Iran Med 18, 277-283, 2015.

Heisler M, Piette JD, Spencer M, Kieffer E, Vijan S. The relationship between knowledge of recent HbAlc values and diabetes care understanding and self-management. Diabetes Care 28, 816-822, 2005.

Hills CE, Brunskill NJ, Squires PE. C-peptide as a therapeutic tool in diabetic nephropathy. Am J Nephrol 31, 389-397, 2010.

Hosseini MS, Rostami Z, Saadat A, Saadatmand SM, Naeimi E. Anemia and microvascular complications in patients with type 2 diabetes mellitus. Nephrourol Mon 6, e19976, 2014.

Inukai T, Matsutomo R, Tayama K, Aso Y, Takemura Y. Relation between the serum level of C-peptide and risk factors for coronary heart disease and diabetic microangiopathy in patients with type-2 diabetes mellitus. Exp Clin Endocrinol Diabetes 107, 40-45, 1999. 
Jones AG, Hattersley AT. The clinical utility of C-peptide measurement in the care of patients with diabetes. Diabet Med 30, 803-817, 2013.

Kim JD, Kang SJ, Lee MK, Park SE, Rhee EJ, Park CY, Oh KW, Park SW, Lee WY. C-peptide-based index is more related to incident type 2 diabetes in non-diabetic subjects than insulin-based index. Endocrinol Metab 31, 320-327, 2016.

Kundu D, Roy A, Mandal T, Bandyopadhyay U, Ghosh E, Ray D. Relation of iron stores to oxidative stress in type 2 diabetes. Niger J Clin Pract 16, 100-103, 2013.

Lee EY, Hwang S, Lee SH, Lee YH, Choi AR, Lee Y, Lee BW, Kang ES, Ahn CW, Cha BS, Lee HC. Postprandial C-peptide to glucose ratio as a predictor of $\beta$-cell function and its usefulness for staged management of type 2 diabetes. J Diabetes Investig 5, 517-524, 2014.

Luppi P, Kallas A, Wahren J. Can C-peptide mediated anti-inflammatory effects retard the development of microvascular complications of type 1 diabetes? Diabetes Metab Res Rev 29, 357-362, 2013.

Mohanram A, Zhang Z, Shahinfar S, Keane WF, Brenner BM, Toto RD. Anemia and end-stage renal disease in patients with type 2 diabetes and nephropathy. Kidney Int 66, 1131-1138, 2004.

Panero F, Novelli G, Zucco C, Fornengo P, Perotto M, Segre O, Grassi G, Cavallo-Perin P, Bruno G. Fasting plasma C-peptide and micro- and macrovascular complications in a large clinic-based cohort of type 1 diabetic patients. Diabetes Care 32, 301-305, 2009.

Ranil PK, Raman R, Rachepalli SR, Pal SS, Kulothungan V, Lakshmipathy P, Satagopan U, Kumaramanickavel G, Sharma T. Anemia and diabetic retinopathy in type 2 diabetes mellitus. J Assoc Physicians India 58, 91-94, 2010.

Rohlfing CL, Wiedmeyer HM, Little RR, England JD, Tennill A, Goldstein DE. Defining the relationship between plasma glucose and $\mathrm{HbA}(1 \mathrm{c})$ : analysis of glucose profiles and $\mathrm{HbA}(1 \mathrm{c})$ in the Diabetes Control and Complications Trial. Diabetes Care 25, 275-278, 2002.

Saisho Y, Kou K, Tanaka K, Abe T, Shimada A, Kawai T, Itoh H. Postprandial serum C-peptide to plasma glucose ratio predicts future insulin therapy in Japanese patients with type 2 diabetes. Acta Diabetol 50, 987-988, 2013.

Saisho Y. Postprandial C-peptide to glucose ratio as a marker of $\beta$ cell function: implication for the management of type 2 diabetes. Int J Mol Sci 17, E744, 2016.

Samnegard B, Jacobson SH, Jaremko G, Johansson BL, Sjoquist M. Effects of C-peptide on glomerular and renal size and renal function in diabetic rats. Kidney Int 60, 1258-1265, 2001.

Sari R, Balci MK. Relationship between C peptide and chronic complications in type-2 diabetes mellitus. J Natl Med Assoc 97, 1113-1118, 2005.

Sato Y, Endo H, Okuyama H, Takeda T, Iwahashi H, Imagawa A, Yamagata K, Shimomura I, Inoue M. Cellular hypoxia of pancreatic $\beta$-cells due to high levels of oxygen consumption for insulin secretion in vitro. J Biol Chem 286, 12524-12532, 2011.

Sato Y, Inoue M, Yoshizawa T, Yamagata K Moderate hypoxia induces $\beta$-cell dysfunction with HIF-1-independent gene expression changes. PLoS One 9, el14868, 2014.

Schnedl WJ, Krause R, Halwachs-Baumann G, Trinker M, Lipp RW, Krejs GJ. Evaluation of HbAlc determination methods in patients with hemoglobinopathies. Diabetes Care 23, 339-344, 2000.

The Diabetes Control and Complications Trial Research Group (The DCCT Research Group). The relationship of glycemic exposure ( $\mathrm{HbAlc}$ ) to the risk of development and progression of retinopathy in the diabetes control and complications trial. Diabetes 44, 968-983, 1995.

Thomas MC, MacIsaac RJ, Tsalamandris C, Power D, Jerums G. Unrecognized anemia in patients with diabetes: a cross-sectional survey. Diabetes Care 26, 1164-1169, 2003.

Thomas MC. Anemia in diabetes: marker or mediator of microvascular disease? Nat Clin Pract Nephrol 3, 20-30, 2007.

Zoppini G, Targher G, Chonchol M, Negri C, Stoico V, Pichiri I, Lippi G, Muggeo M, Bonora E. Anaemia, independent of chronic kidney disease, predicts all-cause and cardiovascular mortality in type 2 diabetic patients. Atherosclerosis 210, 575-580, 2010. 